\title{
Protective Effect of Apis dorsata Honey on Chronic Monosodium Glutamate-Induced Testicular Toxicity in Mus musculus Mice
}

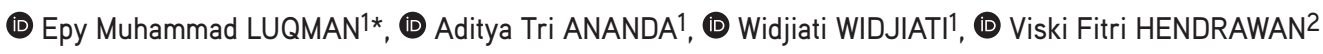 \\ 1Universitas Airlangga, Faculty of Veterinary Medicine, Department of Veterinary Science, Surabaya, Indonesia \\ 2 Universitas Brawijaya, Faculty of Veterinary Medicine, Department of Animal Reproduction, Malang, Indonesia
}

\begin{abstract}
Objectives: This study proves the protective effect of Apis dorsata honey against chronic monosodium glutamate (MSG)-induced testicular toxicity on the Leydig cell necrosis count and malondialdehyde (MDA) serum level in Mus musculus mice.

Materials and Methods: In this study, 25 male mice were used and grouped into two large groups: The control group consisting of negative control (C-) and positive control ( $\mathrm{C}+$ ). C+ group was fed with $4 \mathrm{mg} / \mathrm{g}$ body weight (gBW) of MSG followed by distilled water. The treatment group consisted treatment 1, treatment 2, and treatment 3 groups with $A$. dorsata honey dosage $53.82 \mathrm{mg} / 20 \mathrm{~g}, 107.64 \mathrm{mg} / 20 \mathrm{~g}, 161.46 \mathrm{mg} / 20 \mathrm{~g}$ per os (p.o.), respectively, followed by MSG $4 \mathrm{mg} / \mathrm{g}$ BW of MSG p.o. For the difference analysis between the group used the one-way ANOVA test and Duncan test. Results: The result of this study showed that there was a significant difference between the treatment group and control group ( $p<0.05$ ) in the Leydig cell necrosis count and MDA levels. The highest Leydig cell necrosis count and MDA level were found in C+ with values $13.20 \pm 2.05$ cell and $37.08 \pm 9.17 \mu \mathrm{mol} / \mathrm{L}$ compared to $\mathrm{C}$-, while in the treatment group, T3 showed the lowest Leydig cell necrosis value and MDA level $4.64 \pm 0.55$ cell and $14.22 \pm 2.01 \mu \mathrm{mol} / \mathrm{L}$ compared to the $\mathrm{C}+$ group.

Conclusion: It can be concluded that $A$. dorsata honey could reduce the Leydig cell necrosis number and MDA level of mice (Mus musculus) exposed to MSG.
\end{abstract}

Key words: Reproductive health, Apis dorsata honey, MSG, necrosis, Leydig cells, MDA

\section{INTRODUCTION}

The development of human lifestyles in the era of globalization has led to significant changes in the needs and means of fulfilling nutrition. The fast lifestyle causes people to choose fast food as a fast and cheap alternative. Fast food is an option because of savory taste due to additive added to enhance taste, the most common additive is monosodium glutamate (MSG). ${ }^{1}$ MSG consumption has increased every year in Indonesia from $1.53 \mathrm{~g} /$ capita/day in 1998 to $9.62 \mathrm{~g} /$ capita/day in 2011. ${ }^{2}$ This excessive consumption behavior could damage the reproductive system due to the production of excess free radicals subsequently infertility. ${ }^{3}$

MSG can cause infertility due to the activation of several glutamatergic receptors such as metabotropic glutamic receptor (mGluR), ionotropic GluR, and N-methyl D-aspartate receptor (NMDAR). Activation of these receptors will initiate phospholipase $C(P L C)$ signaling due to activation of $G$ protein and increase intracellular calcium from cells. ${ }^{4}$ Increased calcium levels will increase the production of reactive oxygen species (ROS) in the synapses of hypothalamic neurons and cause ablation. However, the ablation will disrupt the hypothalamic signalling axis - anterior pituitary - testes and interfere with the production of reproductive hormones such as follicle stimulating hormone (FSH) and interstitial cell stimulating hormone (ICSH). ${ }^{3}$

Leydig cell damage is also caused by excessive production of ROS in the tubules and causes cells to be in a state of oxidative stress, which is characterized by increasing 
levels of malondialdehyde (MDA) as a waste product of lipid peroxidation reactions and decreasing glutathione (GSH). The damage caused by ROS can be prevented with exogenous antioxidants because they have the ability to donor the hydrogen ions and neutralize ROS. ${ }^{5}$ Apis dorsata forest honey is multiflora honey that is produced from multiple flowers and nectar. It has a more diverse bioactive antioxidant content than Apis mellifera honey, which is only harvested from one flower. ${ }^{6}$ Based on the explanations above, this study proves the protective effect of $A$. dorsata honey against chronic MSGinduced testicular toxicity with the parameter of the Leydig cell necrosis count and MDA serum level in Mus musculus mice.

\section{MATERIALS AND METHODS}

This research is an experimental laboratory study using a completely randomized design of 25 male mice (Mus musculus) divided into five treatment groups using preventive doses and five replications. Mice were obtained from the Center for Veterinary Farma (PUSVETMA). The mice were then acclimatized for 7 days to minimize stress and were then given a standard feed of Hi-Pro-Vite Medicated 593 feed.

Mice were grouped into two large groups: the control group consisting of negative control (C-) and positive control $(\mathrm{C}+)$ and the treatment group consisting of treatment 1 (T1), treatment 2 (T2), and treatment 3 (T3). The $\mathrm{C}$ - was only given a placebo (aqua dest), the $\mathrm{C}+$ were induced with $4 \mathrm{mg} / \mathrm{g}$ body weight (gBW) MSG and given aqua dest post 1 hour. The treatment group including T1, T2, and T3 was given with $A$. dorsata forest honey with dosages 53.82 mg/20 gBW, 107.64 $\mathrm{mg} / 20 \mathrm{gBW}$, and $161.45 \mathrm{mg} / 20 \mathrm{gBW}$ p.o., respectively, and post $1 \mathrm{~h}$, they were induced with MSG $4 \mathrm{mg} / \mathrm{gBW}$ p.o. The dosage is based on research conducted by for $A$. dorsata forest honey and for MSG doses.7.8 All the treatments were carried out for 52 days.

At the end of the treatment, the mice were euthanized using atlanto-occipital cervical dislocation, then the tests were prepared and put in $10 \%$ formalin solution for histopathological examination with hematoxylin and eosin staining and intracardiac blood collection for MDA level measurement.

Histopathological was examined using a Nikon Eclipse microscope with 400x magnification to observe the number of necrotized Leydig cells. Leydig cell necrosis was counted in five visual fields and then averaged. MDA examination was carried out using serum samples and using the ELISA colorimetric method, whose levels were given units of $\mu \mathrm{mol} / \mathrm{L}$.

\section{Statistical analysis}

For the difference analysis between groups used the one-way ANOVA test and Duncan tests, and the data obtained were analyzed statistically by SPSS 20.00 version. To understand which groups are significant to each other, the superscripts $(a, b, c, d)$ show the different values and different superscripts show significant differences between the groups.

\section{RESULTS AND DISCUSSION}

The average number of necrotic Leydig cells was observed on histopathological preparations using the Nikon Eclipse E-100 and calculated using a raster image application with a magnification of $400 x$ in five fields of view. MDA levels were measured using a colorimetric method using a spectrophotometer with an absorbance of $450 \mathrm{~nm}$, which was then compared with a standard curve. Generally, the results showed that there was a significant difference ( $p<0.05$ ) between the control group and treatment groups in the Leydig cell necrosis count and MDA serum level.

In the Leydig cell necrosis count, there were significant differences between the control group and the treatment group as shown in Table 1 and in the Figure 1 showing necrotic Leydig cells marked with pyknotic. In the control group, the highest necrosis cell count was found in $\mathrm{C}+$ with $13.20 \pm 2.05$ cells, this value is significantly different with $\mathrm{T} 1, \mathrm{~T} 2, \mathrm{~T} 3$, and $\mathrm{C}$ - (as shown with different superscript), meanwhile, the lowest necrosis cell count was found in $\mathrm{C}$ - with $2.56 \pm 0.51$ cells and significantly different with $\mathrm{C}_{+}, \mathrm{T} 1, \mathrm{~T} 2$, and T3. In the treatment group consisting of T1, T2, and T3, the T3 group with the highest dose of $A$. dorsata forest honey had the lowest necrosis cell count of $4.64 \pm 0.55$ cells and is significantly different compared to another treatment group ( $\mathrm{T} 1$, and $\mathrm{T} 2$ ) and control group ( $\mathrm{C}$ - and $\mathrm{C}+$ ). These results indicated that along with an increasing dose of $A$. dorsata honey given in MSG-induced testicular toxicity, there was a decrease in Leydig cell necrosis count even though T3 is still significantly different with the lowest value in C-.

MDA serum-level results are shown in Table 2 . There were significant differences between the groups. In the control group, $\mathrm{C}+$ was significant with $\mathrm{C}$ - and all treatment groups ( $\mathrm{T} 1$, $\mathrm{T} 2$, and T3) but $\mathrm{C}$ - was only significant with $\mathrm{C}_{+}$, and $\mathrm{T} 1$ and not significantly different with T2 and T3. The $\mathrm{C}+$ had the highest value $(37.08 \pm 9.17)$ compared to all groups and the lowest MDA value was found in $\mathrm{C}$ - $(11.87 \pm 3.81)$. In the treatment group consisting of $\mathrm{T} 1, \mathrm{~T} 2$, and $\mathrm{T} 3$, the $\mathrm{T} 3$ group with the highest dose of $A$. dorsata forest honey had the lowest MDA serum level $14.22 \pm 2.01$, although it was not significantly different with

$\begin{aligned} & \text { Table 1. The average number of necrotic Leydig cells in each } \\
& \text { group }\end{aligned}$
\begin{tabular}{ll} 
Group & Leydig cell necrosis number (mean \pm SD) \\
\hline C- & $2.56^{\mathrm{e}} \pm 0.51$ \\
\hline C+ & $13.20^{\mathrm{a}} \pm 2.05$ \\
\hline T1 & $9.84^{\mathrm{b}} \pm 0.74$ \\
\hline T2 & $8.12^{\mathrm{c}} \pm 1.08$ \\
\hline T3 & $4.64^{\mathrm{d}} \pm 0.55$ \\
\hline
\end{tabular}

a, b, c, dMeans within the same column with differing superscripts are significantly different ( $p<0.05$ ). C-: Control (distilled water). C+: MSG p.o. 4 $\mathrm{mg} / \mathrm{gBW}+$ distilled water. T1: Apis dorsata p.o. $(53.82 \mathrm{mg} / 20 \mathrm{~g})+\mathrm{MSG}$ p.o. 4 $\mathrm{mg} / \mathrm{gBW}$. T2: Apis dorsata honey p.o. (107.64 mg/20 g) + MSG p.o. $4 \mathrm{mg} / \mathrm{gBW}$. T3: Apis dorsata p.o. honey $(161.46 \mathrm{~g} / 20 \mathrm{~g})+\mathrm{MSG}$ p.o. $4 \mathrm{mg} / \mathrm{gBW}$. All treatments were carried out for 52 days. C+: Positive control, C-: Negative control, SD: Standard deviation, T: Treatment, MSG: Monosodium glutamate, gBW: Gram body weight, p.o.: Per os 
T2 $17.65 \pm 5.72$ and compared to $\mathrm{C}$ - in the control group. The results also showed that the treatment group values, including $\mathrm{T} 1, \mathrm{~T} 2$, and $\mathrm{T} 3$, are significantly different from $\mathrm{C}+$ in the control group. These results indicated that the MDA value of each treatment group decreased with the dose of $A$. dorsata honey in the treatment group (T1, T2, and T3) and was statistically significant compared with $\mathrm{C}+$ even though the lowest value of MDA was in the $\mathrm{C}$ - group.
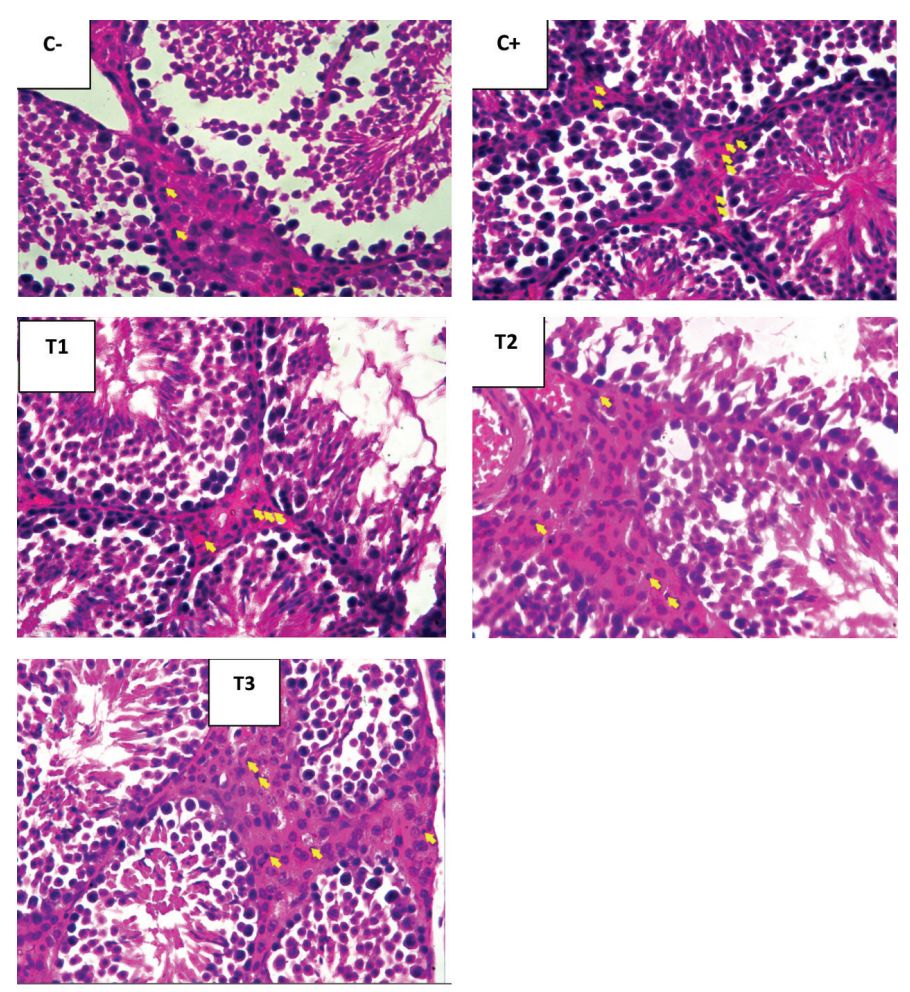

Figure 1. The testicular histopathology (HE) of mice (Mus musculus) given Apis dorsata forest honey as a preventive dose with a magnification of 400x, yellow arrows showed necrotic Leydig cells marked with pyknotic. C-: Control (distilled water). C+: MSG p.o. $4 \mathrm{mg} / \mathrm{gBW}$ + distilled water. T1: Apis dorsata p.o. (53.82 mg/20 g) + MSG p.o. $4 \mathrm{mg} / \mathrm{gBW}$. T2: Apis dorsata honey p.o. $(107.64 \mathrm{mg} / 20 \mathrm{~g})+\mathrm{MSG}$ p.o. $4 \mathrm{mg} / \mathrm{gBW}$. T3: Apis dorsata p.o. honey $(161.46 \mathrm{~g} / 20 \mathrm{~g})+\mathrm{MSG}$ p.o. $4 \mathrm{mg} / \mathrm{gBW}$. All treatments were carried out for 52 days. HE: Hematoxylin and eosin, C+: Positive control, C-: Negative control, T: Treatment, gBW: Gram body weight, p.o.: Per os

Table 2. MDA levels in serum

\begin{tabular}{ll} 
Group & MDA level $(\mu \mathrm{mol} / \mathrm{L})($ mean \pm SD $)$ \\
\hline $\mathrm{C}-$ & $11.87^{\mathrm{c}} \pm 3.81$ \\
\hline $\mathrm{C}+$ & $37.08^{\mathrm{a}} \pm 9.17$ \\
\hline $\mathrm{T} 1$ & $23.87^{\mathrm{b}} \pm 11.88$ \\
\hline T2 & $17.65^{\mathrm{bc}} \pm 5.72$ \\
\hline T3 & $14.22^{\mathrm{bc}} \pm 2.01$ \\
\hline
\end{tabular}

$a, b, c$ Means within the same column with differing superscripts are significantly different ( $p<0.05$ ). C-: Control (distilled water). C+: MSG p.o. $4 \mathrm{mg} / \mathrm{gBW}+$ distilled water. T1: Apis dorsata p.o. (53.82 mg/20 g) + MSG p.o. $4 \mathrm{mg} / \mathrm{gBW}$. T2: Apis dorsata honey p.o. (107.64 mg/20g) + MSG p.o. $4 \mathrm{mg} / \mathrm{gBW}$. T3: Apis dorsata p.o. honey $(161.46 \mathrm{~g} / 20 \mathrm{~g})+\mathrm{MSG}$ p.o. $4 \mathrm{mg} / \mathrm{gBW}$. All treatments were carried out for 52 days. MDA: Malondialdehyde, C+: Positive control, C-: Negative control, SD: Standard deviation, T: Treatment, gBW: Gram body weight, p.o.: Per os
Chronic consumption of MSG will increase L-glutamate levels in blood vessels, which will activate the mGluR then will increase the binding activity of D-aspartate with NMDAR. ${ }^{8}$ Normally, in the steroidogenesis process, NMDAR is activated via the mitogen-activated protein kinases (MAPK) and cyclic adenosine monophosphate signaling pathways to activate the steroidogenic acute regulatory (STAR) protein complex, which actively converts cholesterol into testosterone through biosynthesis of testosterone. ${ }^{9}$

Chronic high L-glutamate levels in the blood will increase the influx of $\mathrm{Ca}^{2+}$ in the hypothalamic nerve synapses and will cause nerve cell death due to excessive excitation known as excitotoxicity. ${ }^{4}$ This condition will cause ablation of the hypothalamic neuron cells and affect the hypothalamuspituitary-testis axis and affect the production of ICSH directly. ${ }^{3}$ This is evidenced by a study conducted by ${ }^{10}$ that there was a significant decrease in ICSH levels along with the increase in the dose of MSG induction.

The disruption of the endocrine axis will cause a hypostimulation state in Leydig cells. ${ }^{3}$ However, excessive NMDAR stimulation facilitates excessive intracellular $\mathrm{Ca}^{2+}$ secretion and stimulates the activation of ROS-forming enzymes such as xanthine oxidase, lipoxygenase, and NADPH oxidase. Excessive production of ROS will result in a state, where endogenous antioxidants such as GSH and superoxide dismutase are unable to keep up the production of ROS, known as oxidative stress." The excessive activation will disrupt MAPK signaling pathway; so that, it will interfere with the STAR-mediated steroidogenesis process. ${ }^{12}$

ROS will bind to polyunsaturated fatty acid (PUFA) and initiate a lipid peroxidation event, where a chain reaction occurs which results in a radical lipid. Oxidized lipid cell membranes will produce MDA and 4-hydroxinonenal (4-NHE), which are toxic to tissues, especially reproductive tissue. ${ }^{11}$ Increased levels of MDA were positively correlated with cell necrosis and tissue damage. ${ }^{13}$ This statement was proved by administering MSG $4 \mathrm{mg} / \mathrm{gBW}$ in the $\mathrm{C}+$, which increased the number of necrotic Leydig cells $(13.20 \pm 2.05)$ and an increase in MDA levels (37.08 $\pm 9.17 \mu \mathrm{mol} / \mathrm{L}$ ) compared to the $\mathrm{C}$ - and the treatment groups ( $\mathrm{T} 1$, T2, and T3).

In the treatment group, there was a decrease in the number of necrotic Leydig cells sequentially along with an increase in the preventive dose of $A$. dorsata forest honey. In the T3 group, the minimum number of necrotic Leydig cells was $4.64 \pm 0.55$ cells and significantly different compared to $C+13.20 \pm 2.05$ cells ( $p$ <0.05). In the MDA level analysis using the colorimetric method, the T3 group showed the lowest MDA level of 14.22 $\mu \mathrm{mol} / \mathrm{L}$ and was significantly different compared with the $\mathrm{C}+$ group $37.08 \pm 9.17 \mu \mathrm{mol} / \mathrm{L}(p<0.05)$ and not significantly different $(p>0.05)$ with $C-11.87 \pm 3.81 \mu \mathrm{mol} / \mathrm{L}$. These results are closely related to the potential of $A$. dorsata forest honey as an antioxidant and testicular protector potential.

The content of $A$. dorsata forest honey consists of flavonoids, phenolic components, enzymatic antioxidants such as (glucose oxidase, catalase), carotenoids, amino acids, and vitamin C 
(ascorbic acid). ${ }^{6}$ Phenolic analysis of $A$. dorsata forest honey by ${ }^{14}$ showed the highest yield of 352.73 gallic acid equivalent compared to $A$. mellifera honey at 186.70 gallic acid equivalent and Apis cerana at 206.33 gallic acid equivalent. $A$. dorsata forest honey also has antioxidant potential measured using DPPH radical scavenging method leading to $\mathrm{IC}_{50}$ of $5453.57 \mathrm{ppm} .^{15}$ This high antioxidant potential can overcome the formation of ROS caused by MSG.

The phenolic compounds present in $A$. dorsata forest honey play an important role in inactivation of ROS produced by excessive NMDAR activation. Anthraquinone compounds reduce ROS such as singlet oxygen, hydroxyl radical, and superoxide, make these radicals inactive and unable to bind to PUFAs thus preventing auto-oxidation. ${ }^{16}$ The content of vitamin $\mathrm{C}$ in $A$. dorsata forest honey also acts as a chain-breaking antioxidant that protects PUFAs. The content of flavonoids also plays a role in chelating transition metals such as Fe (II), Fe (III), and Cu (II) that play a role in the formation of ROS. ${ }^{17}$ In this study, giving forest honey as a preventive dose was proved to reduce the number of necrotic Leydig cells and reduce MDA levels.

However, forest honey also plays a role in preventing hypothalamic ablation caused by excitotoxicity and reducing oxidative stress that occurs in the brain due to excessive excitatory postsynaptic stimulation of neurons. Repair in the hypothalamus-pituitary-testicular axis directly normalizes ICSH production from the anterior pituitary and normalizes the function of steroidogenesis. ${ }^{3}$ Through this mechanism, giving $A$. dorsata forest honey a preventive dose can prevent oxidative stress caused by chronic MSG consumption by reducing the number of necrotic Leydig cells and decreasing MDA levels.

\section{CONCLUSION}

This study concludes that giving $A$. dorsata forest honey as a preventive dose can reduce the Leydig cells necrotic counts and MDA levels of in mice that are chronically exposed to MSG.

\section{ACKNOWLEDGMENTS}

The authors express sincere thanks to the Ministry of Research, Technology and Higher Education of the Republic of Indonesia for funding research and the Dean of Faculty of Veterinary Medicine for providing all necessary facilities and fund for conducting research work.

\section{Ethics}

Ethics Committee Approval: This research received ethical clearance number: 1. KE.075.08.2020 released by the Animal Care and Use Committee, Faculty of Veterinary Medicine Universitas Airlangga.

Informed Consent: Not applicable.

Peer-review: Externally peer-reviewed.

\section{Authorship Contributions}

Concept: E.M.L., A.T.A., W.W., V.F.H., Design: E.M.L., A.T.A., W.W., V.F.H., Data Collection or Processing: E.M.L., A.T.A., W.W., V.F.H., Analysis or Interpretation: E.M.L., A.T.A.,
W.W., V.F.H., Literature Search: E.M.L., A.T.A., W.W., V.F.H., Writing: E.M.L., A.T.A., W.W., V.F.H.

Conflict of Interest: No conflict of interest was declared by the authors.

Financial Disclosure: Implementation of Internal Research Universitas Airlangga (Grant \# 346/UN3/2020).

\section{REFERENCES}

1. Niaz K, Zaplatic E, Spoor J. Extensive use of monosodium glutamate: a threat to public health? EXCLI J. 2018;17:273-278.

2. Nuraida L, Madaniyah S, Nuri Andarwulan SN, Briawan D, Lioe HN, Zulaikhah Z. Free glutamate intake from foods among adults: case study in Bogor and Jakarta. J Mutu Pangan. 2014;1:100-109.

3. Kayode OT, Rotimi DE, Kayode AAA, Olaolu TD, Adeyemi OS. Monosodium glutamate (MSG)-induced male reproductive dysfunction: a mini review. Toxics. 2020;8:7.

4. Jakaria M, Park SY, Haque M, Karthivashan G, Kim IS, Ganesan P, Choi DK. Neurotoxic agent-induced injury in neurodegenerative disease model: focus on involvement of glutamate receptors. Front Mol Neurosci. 2018;11:307-327.

5. Yang JM, Arnush M, Chen QY, Wu XD, Pang B, Jiang XZ. Cadmiuminduced damage to primary cultures of rat Leydig cells. Reprod Toxicol. 2003;17:553-560.

6. Saputri DS, Putri YE. Antioxidant activity of forest honey in some regions Sumbawa district. JTambora. 2017;2:1-5.

7. Rista R, Yuziani Y. The effectiveness of honey on increasing $\mathrm{Hb}$ in white rats. Jurnal Edukasi dan Sains Biologi. 2014;3:7-13. Available from: https://media.neliti.com/media/publications/77158-ID-efektifitas-maduterhadap-peningkatan-hb.pdf

8. Agustina W, Widayati A, Hayati A. Effects of red fruit (Pandanus conoideus Lam) oil on malondialdehyde level and spermatozoa quality in mice (Mus musculus) exposed to monosodium glutamate. Folia Med Indonesiana. 2018;54:84-88.

9. Zhang SY, Ito Y, Yamanoshita O, Yanagiba Y, Kobayashi M, Taya K, Li C, Okamura A, Miyata M, Ueyama J, Lee CH, Kamijima M, Nakajima T. Permethrin may disrupt testosterone biosynthesis via mitochondrial membrane damage of Leydig cells in adult male mouse. Endocrinology. 2007;148:3941-3949.

10. Edward Z. Effect of giving monosodium glutamate (MSG) in male rats (Rattus norvegicus) on FSH and LH. Majalah Kedokteran Andalas. 2015;34:160-166.

11. Asadi N, Bahmani M, Kheradmand A, Rafieian-Kopaei M. The impact of oxidative stress on testicular function and the role of antioxidants in improving it: a review. J Clin Diagn Res. 2017;11:IE01-IE05.

12. Diemer T, Allen JA, Hales KH, Hales DB. Reactive oxygen disrupts mitochondria in MA-10 tumor Leydig cells and inhibits steroidogenic acute regulatory (StAR) protein and steroidogenesis. Endocrinology. 2003;144:2882-2891.

13. Rahardjani KB. The relationship between malondialdehyde (MDA) and the outcome of neonatal sepsis. Sari Pediatri. 2016;12:82-87.

14. Moniruzzaman M, Sulaiman SA, Khalil MI, Gan SH. Evaluation of physicochemical and antioxidant properties of sourwood and other Malaysian honeys: a comparison with manuka honey. Chem Cent J. 2013;7:138. 
15. Apak R, Güçlü K, Demirata B, Ozyürek M, Celik SE, Bektaşoğlu B, Berker KI, Ozyurt D. Comparative evaluation of various total antioxidant capacity assays applied to phenolic compounds with the CUPRAC assay. Molecules. 2007;12:1496-1547.

16. Lakshman S, Murthy YLN, Rao KRM. Studies on synthesis and antioxidant property of anthraquinone analogues. Mater Today: Proc. 2021;40(Suppl 1):S75-S78.
17. Santos-Sánchez NF, Salas-Coronado R, Villanueva-Cañongo C, Hernández-Carlos B. Antioxidant compounds and their antioxidant mechanism. in E. Shalaby (ed.), Antioxidants, IntechOpen, London. 10.5772/intechopen.85270. 